Polymer Journal, Vol. 39, No. 4, pp. 298-303 (2007)

(C) 2007 The Society of Polymer Science, Japan

\title{
Two Dimensional and Three Dimensional Interactions between Bovine Serum Albumin and Chondroitin Sulfate
}

\author{
Shouhong $\mathrm{Xu}^{1, \dagger}$ and Masakatsu YoNESE ${ }^{2}$ \\ ${ }^{1}$ Department of Chemistry, East China University of Science and Technology, 130 Meilong-Road 200237, Shanghai, China. \\ ${ }^{2}$ Graduate School of Pharmaceutical Sciences, Nagoya City University, Tanabe-dori, Mizuho-ku, Nagoya 467-8603, Japan
}

(Received October 2, 2006; Accepted December 23, 2006; Published February 26, 2007)

\begin{abstract}
The interaction between glycosaminoglycan and protein in solution and at interface are important for the biofunctions of tissues. We previously reported that the binding behavior between sodium hyaluronate NaHA and bovine serum albumin BSA both in solution and at interface. Here, two- and three-dimensional interactions between sodium chondroitin sulfate $\mathrm{Na}_{2} \mathrm{ChS}$ and BSA were studied by an electrophoretic light scattering ELS and a quartz crystal microbalance QCM method. $\mathrm{Na}_{2} \mathrm{ChS}$ molecules bound to BSA molecules by an electrostatic force and form soluble complex in solution. Their molar ratio $\gamma=n_{\mathrm{BSA}} / n_{\mathrm{ChS}}$ of the saturated complex was about $6-7$. However, the value of $\gamma$ was about 1 at interface when the binding between $\mathrm{Na}_{2} \mathrm{ChS}$ and BSA became saturated. $\mathrm{Na}_{2} \mathrm{ChS}$ molecules could adsorb onto a BSA monolayer by a hydrophobic force in a Langmuir type. Its adsorption layer was a double-layer structure from the results. The results of $\mathrm{Na}_{2} \mathrm{ChS}$-BSA complex in solution and at interface were discussed by comparing with the binding behavior between sodium hyaluronate NaHA and BSA to elucidate the effects of the sulfate group and charge density of $\mathrm{Na}_{2} \mathrm{ChS}$. [doi:10.1295/polymj.PJ2006123]

KEY WORDS $\quad \mathrm{Na}_{2} \mathrm{ChS} / \mathrm{BSA} / \mathrm{Two}$ Dimensional Interaction / Three Dimensional Interaction / $\mathrm{QCM} /$
\end{abstract}

Glycosaminoglycans are the primary parts of connective tissues, such as skin, cartilage and glass body fluids. They widely distributed in a monomer state and/or a complex state combining with protein, termed proteoglycans, and play important physiological roles in the cell and extracellullar matrix. ${ }^{1}$ Glycosaminoglycans are negatively charged polysaccharides, which are classified on the basis of structure into several groups such as hyaluronan HA, chondroitin sulfate $\mathrm{ChS}$, heparatan sulfate, keratin sulfate and dermatan sulfate. They are studied extensively in many fields especially in biochemistry and medical regions because of their important biofunction. For example, they are tried to use in the treatment of osteoarthritis. ${ }^{2-5}$ in the ophthalmologic surgery of cataract, ${ }^{6}$ in the preparation of implant biomaterials, ${ }^{7,8}$ in the therapy of skin wound, ${ }^{9}$ and so on. Their chemical structures are reported to be linear polysaccharides composed of repeating disaccharide units of glucuronic acid and $N$-acetylgalatosamine, ${ }^{10,11}$ but different in the kinds of the charged groups, the charge density and the linked positions. ChS is sulfated at every repeating unit in the position 4 or 6 as shown in the following schematic representative structures and its charge density is two times as much as that of HA. These differences determine their different physicochemical properties, biological and pharmacological activities in bodies. ${ }^{12,13}$ From the physico-chemical point of view, their shapes, properties and the interac- tions with proteins in solution have been reported extensively, but the binding behaviors with protein at interface are studied scarcely.

In our laboratory, the structure and interaction between polysaccharides and proteins were not only studied in solution, but also at interface. We reported in solution, nano-particles formed between HA and bovine serum albumin BSA. The complex particles changed their shapes from worm-like to random-coil ones and decreasing the size with increasing the molar ratio of BSA to HA. ${ }^{14,15}$ At interface, HA could form a net-work nanostructure on BSA monolayer and their aperture size could be controlled by the molecular weight of HA. Their two-dimensional and three dimensional nano-structures and properties are considered to be related to their bio-functions in living tissues. ${ }^{16-20}$ Here, to elucidate the effects of the charge densities of polysaccharudes, the system of BSA-

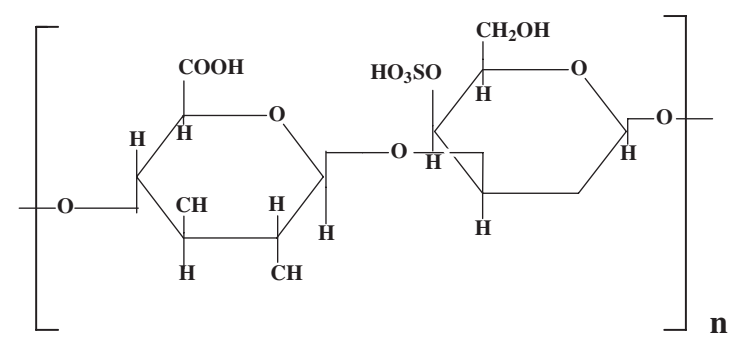

Scheme 1. The schematic representative structures of ChS.

${ }^{\dagger}$ To whom correspondence should be addressed (Tel: +86-21-64252218, Fax: +86-21-64252485, E-mail: xushou@ yahoo.co.jp). 
ChS was selected to study and compare with those of BSA-HA.

It was already reported that BSA-ChS complexes could be formed stably in solution. ${ }^{21}$ In this work, the two- and three-dimensional interaction between sodium chondroitin sulfate $\mathrm{Na}_{2} \mathrm{ChS}$ and BSA were studied by an electrophoretic light scattering ELS and a quartz crystal microbalance QCM method. The results of $\mathrm{Na}_{2} \mathrm{ChS}$-BSA complex in solution and at interface were discussed by comparing with the binding behavior between sodium hyaluronate NaHA and BSA to elucidate the effects of the sulfate group and charge density of $\mathrm{Na}_{2} \mathrm{ChS}$.

\section{EXPERIMENTAL}

\section{Materials}

Sodium chondroitin sulfate A $\left(M_{\mathrm{w}}=23,000\right.$ $\mathrm{g} \mathrm{mol}^{-1}$ ) $\mathrm{Na}_{2} \mathrm{ChS}$ was of a commercial origin (Seikagaku kogyou Co. (Tokyo)). Bovine Serum Albumin BSA was purified by delipidzing a BSA Fraction V (Seikagaku kogyou). ${ }^{15}$ Its average molecular weight was determined to be $M_{\mathrm{w}}=70,000 \mathrm{~g} \mathrm{~mol}^{-1}$ using a static light scattering. The water used here was deionized and distilled.

\section{Preparation of Complex Solution Composed of $\mathrm{Na}_{2}$ -} ChS and BSA

Various amounts of BSA $\left(C_{\mathrm{BSA}}=0-57 \mu \mathrm{mol}\right.$ $\mathrm{dm}^{-3}$ ) were added to the $\mathrm{Na}_{2} \mathrm{ChS}$ solution of which concentration was $4.3 \mu \mathrm{mol} \mathrm{dm}{ }^{-3}$. The molar ratio of BSA to $\mathrm{Na}_{2} \mathrm{ChS} \gamma=n_{\mathrm{BSA}} / n_{\mathrm{ChS}}$ is in the region of 0 to 13.3 . The ionic strength $J$ was $0.001 \mathrm{~mol} \mathrm{dm}^{-3}$, which was adjusted by $\mathrm{NaCl}$. The solutions were kept in sealed vessel in refrigerator over $24 \mathrm{~h}$ before measurement and used in 3-4 d.

\section{Measurement of Viscosity and $\mathrm{pH}$}

The viscosities of complex solutions composed of $\mathrm{Na}_{2} \mathrm{ChS}$ and BSA were measured by using an Ostward-type viscometer at $25^{\circ} \mathrm{C}$. The $\mathrm{pH}$ value was obtained by using a digital $\mathrm{pH} / \mathrm{mV}$ meter (Orion model 701A).

\section{Measurement of Electrophoretic Mobility}

The electrophoretic mobilities of complex solutions composed of $\mathrm{Na}_{2} \mathrm{ChS}$ and BSA were measured at $25^{\circ} \mathrm{C}$ using an electrophoretic light scattering photometer (Otsuka Electronics Co., LEZA-600, $\lambda=$ $632.8 \mathrm{~nm})$.

\section{Measurement of Activities of $\mathrm{Na}^{+}$}

The activities of $\mathrm{Na}^{+}$ion of $\mathrm{Na}_{2} \mathrm{ChS}$ solution and complex solutions composed of $\mathrm{Na}_{2} \mathrm{ChS}$ and BSA were measured at $25^{\circ} \mathrm{C}$ using a $\mathrm{pH} /$ ion meter (Orion
920A), which was connected with a double junction reference electrode (Orion Co., No. 900200).

\section{Measurement of Adsorption of $\mathrm{Na}_{2} \mathrm{ChS}$ on BSA Mono- layer}

BSA adsorbed monolayers were prepared as reported in a previous paper ${ }^{16,17}$ which were used as a BSA tip in this experiment. The BSA tip was immersed into various concentrations of $\mathrm{Na}_{2} \mathrm{ChS}$ solution $C_{\mathrm{ChS}}$ $\left(C_{\mathrm{ChS}}=2.2-22 \times 10^{-8} \mathrm{~mol} \mathrm{dm}^{-3}, \quad J=0.001 \mathrm{~mol}\right.$ $\left.\mathrm{dm}^{-3}\right)$. The adsorption mass of $\mathrm{Na}_{2} \mathrm{ChS}$ on BSA monolayer was measured using a QCM whose resonance frequency is $9 \mathrm{MHz}$. According to Sauerbrey's equation, ${ }^{22,23}$ the frequency decreased of $1 \mathrm{~Hz}$ corresponding to a mass increase of $0.87 \mathrm{ng}$ on the QCM electrodes.

\section{RESULTS}

The Relative Viscosity $\eta_{\text {rel }}$ of the Complex Solution Composed of $\mathrm{Na}_{2} \mathrm{ChS}$ and BSA

The complexes composed of $\mathrm{Na}_{2} \mathrm{ChS}$ and BSA were prepared by adding various amounts of BSA $\left(0-57 \mu \mathrm{mol} \mathrm{dm}^{-3}\right)$ into the $\mathrm{Na}_{2} \mathrm{ChS}$ solution, whose value of $\gamma$ was in the region of 0 to 13.3. And no phase separation could be found in this region of the concentration. As shown in Figure 1, the result of $\eta_{\text {rel }}$ were almost constant in the experimental region. A viscosity of polymer solution depends on a concentration, a structure, a shape and a size of molecule. The size of complexes composed of BSA and $\mathrm{Na}_{2} \mathrm{ChS}$ were reported to become a little longer and thicker, and change little in shape comparing with $\mathrm{Na}_{2} \mathrm{ChS}$ molecule. ${ }^{21}$ Furthermore, the concentrations of the complex solutions were very low in this experiment. Then, the value of $\eta_{\text {rel }}$ were almost unchanged when $\gamma$ increased from 0 to 13.3 as shown in Figure 1.

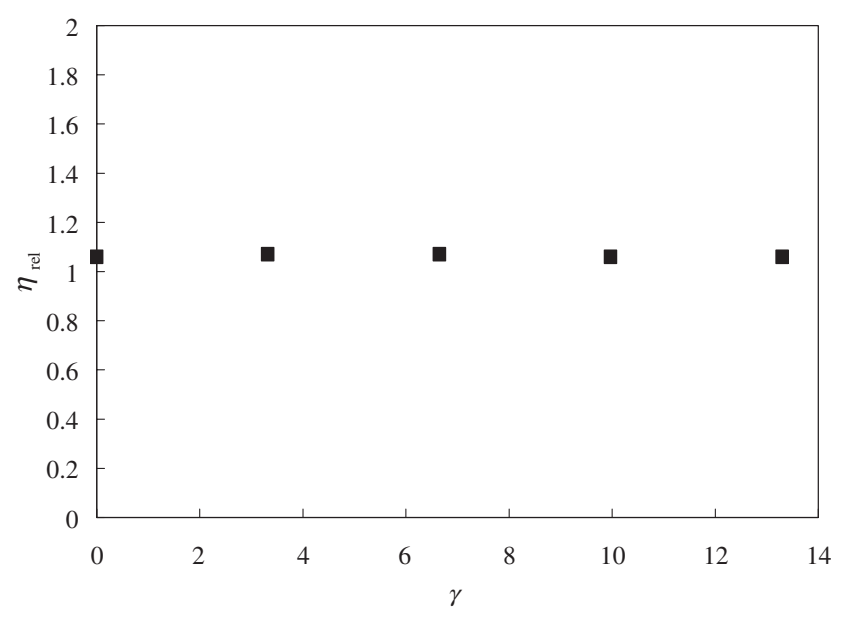

Figure 1. Relative viscosities of complex solutions composed of $\mathrm{Na}_{2} \mathrm{ChS}$ and BSA plotted against $\gamma\left(J=0.001 \mathrm{~mol} \mathrm{dm}^{-3}\right)$. 


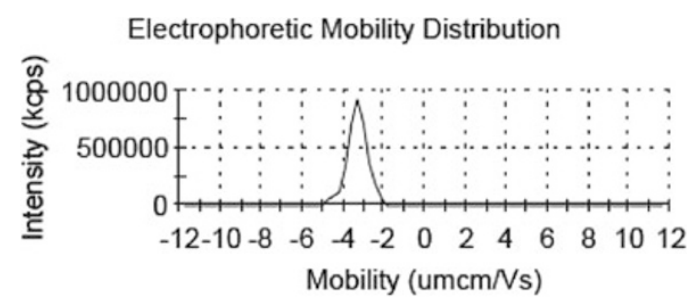

(a)

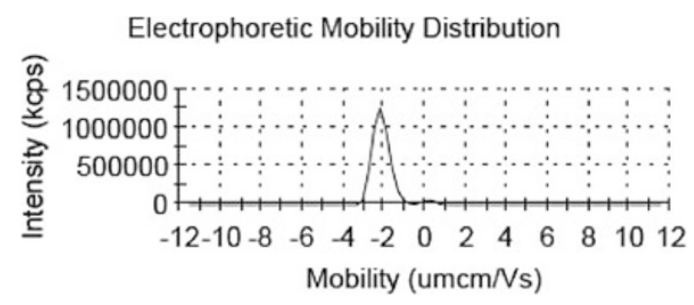

(b)

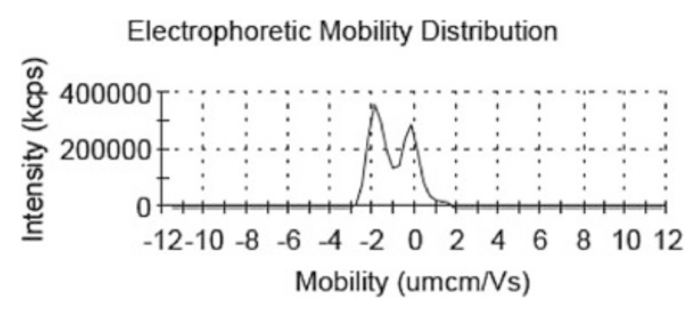

(c)

Figure 2. Spectra of mobility of $\mathrm{Na}_{2} \mathrm{ChS}$ and complexes composed of $\mathrm{Na}_{2} \mathrm{ChS}$ and BSA at various $\gamma$. (a) Spectra of mobility of $\mathrm{Na}_{2} \mathrm{ChS}$ solution $(\gamma=0)$. (b) Spectra of mobility of $\mathrm{Na}_{2} \mathrm{ChS}$-BSA complex solution at $\gamma=6.7$. (c) Spectra of mobility of $\mathrm{Na}_{2} \mathrm{ChS}$ BSA complex solution at $\gamma=10$.

However, the results of NaHA were different from those of $\mathrm{Na}_{2} \mathrm{ChS}$ as reported in a previous paper. ${ }^{15}$ The viscosities of the complex solution composed of NaHA $\left(M_{\mathrm{w}}: 850,000 \mathrm{~g} \mathrm{~mol}^{-1}\right)$ and BSA decreased obviously with increasing the binding amount of BSA to NaHA. From those results, we concluded that differing from $\mathrm{Na}_{2} \mathrm{ChS}$ the NaHA molecules changed their shapes from a worm like structure to a shrunken random coil structure after binding to BSA molecules.

\section{Electrophoretic Mobility U of Complex Solution Com- posed of $\mathrm{Na}_{2} \mathrm{ChS}$ and BSA}

Electrophoretic mobilities $U$ of the complex solutions composed of $\mathrm{Na}_{2} \mathrm{ChS}$ and BSA were measured at $25^{\circ} \mathrm{C}$ by ELS in the same concentration region as mentioned above. Figure 2 shows the spectra of mobility of $\mathrm{Na}_{2} \mathrm{ChS}$-BSA complexes at various $\gamma$. Figure 2(a) is the result of $\mathrm{Na}_{2} \mathrm{ChS}$ solution, which showed a single peak in the negative region. And Figure 2(b) and (c) are the solutions of $\gamma=6.7$ and 10. Figure 2(b) also showed a single peak, which indicates the $\mathrm{Na}_{2} \mathrm{ChS}$ and $\mathrm{BSA}$ molecules formed a complex and almost no free BSA or $\mathrm{Na}_{2} \mathrm{ChS}$ molecules

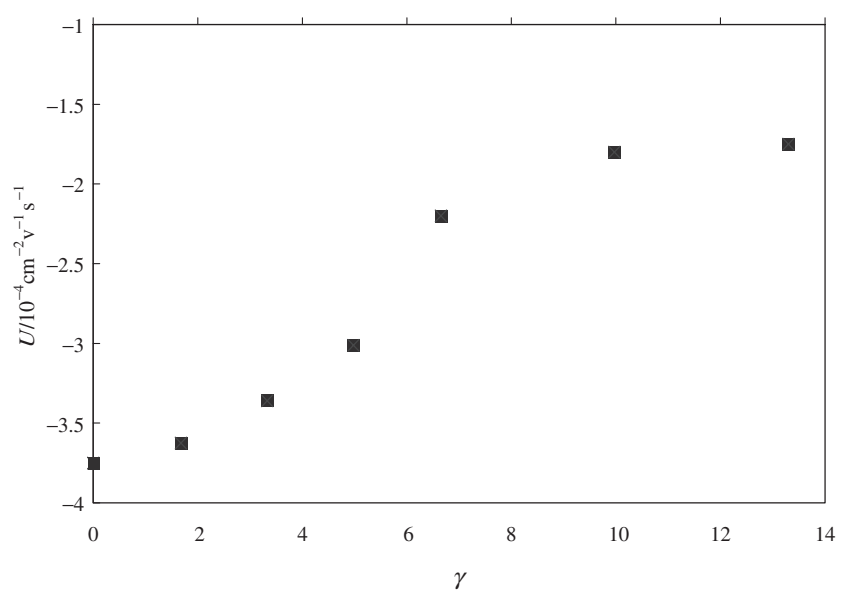

Figure 3. Electrophoretic mobility of complexes composed of $\mathrm{Na}_{2} \mathrm{ChS}$ and BSA plotted against $\gamma$.

exist. However, two peaks appeared in the result of $\gamma=10$ as shown in Figure 2(c). The second peak nearing zero should be contributed by free BSA molecules because the mobility of BSA is almost zero at that $\mathrm{pH}$.

The results of $U$ of the complex solutions are shown in Figure 3 as a function of $\gamma$. The value of $U$ of $\mathrm{Na}_{2} \mathrm{ChS}$ solution was $-3.65 \times 10^{4} \mathrm{~cm}^{2} \mathrm{v}^{-1} \mathrm{~s}^{-1}$ shown at the point of $\gamma=0$. The values of $U$ of the complexes increased with increasing $\gamma$ and became almost constant in the region of $\gamma>6.7$. This indicates the formation of a saturated complex. Increasing the value of $\gamma$ more, free BSA molecules began to appear and two peaks were observed. The value of $U$ in the region of $\gamma>6.7$ was contributed by complexes and free BSA molecules. The values of $U$ in the region of $\gamma>6.7$ shown in Figure 3 selected the value of complex peak.

\section{Increase of Concentration of Free $\mathrm{Na}^{+}$Ion $\mathrm{C}_{\mathrm{Na}}$ Due} to Complex Formation

There are a carboxylic group and a sulfate group in every repeating disaccharide units of $\mathrm{Na}_{2} \mathrm{ChS}$. When mixed $\mathrm{Na}_{2} \mathrm{ChS}$ with BSA molecules, complexes were formed by binding BSA molecules to carboxylic groups $\left(-\mathrm{COO}^{-}\right)$and sulfate groups $\left(-\mathrm{HOSO}_{3}{ }^{-}\right)$of $\mathrm{Na}_{2} \mathrm{ChS}$ and consequently $\mathrm{Na}^{+}$ions release from carboxylic groups and sulfate groups simultaneously. Then, the value of $C_{\mathrm{Na}+}$ should increase. The activities of $\mathrm{Na}^{+}$ion of the complex solutions were measured by using a $\mathrm{Na}^{+}$ion electrode at $25^{\circ} \mathrm{C}$. The activity coefficients were approximated to be 1 because of the low concentration.

Figure 4 shows the results of $C_{\mathrm{Na}+}$ of the complex solutions as a function of $\gamma$. The value of $C_{\mathrm{Na}+}$ at $\gamma=0$ is the contribution of $\mathrm{Na}_{2} \mathrm{ChS}$ and $\mathrm{NaCl}$ ion strength. With increasing $\gamma$, the value of $C_{\mathrm{Na}+}$ increas- 


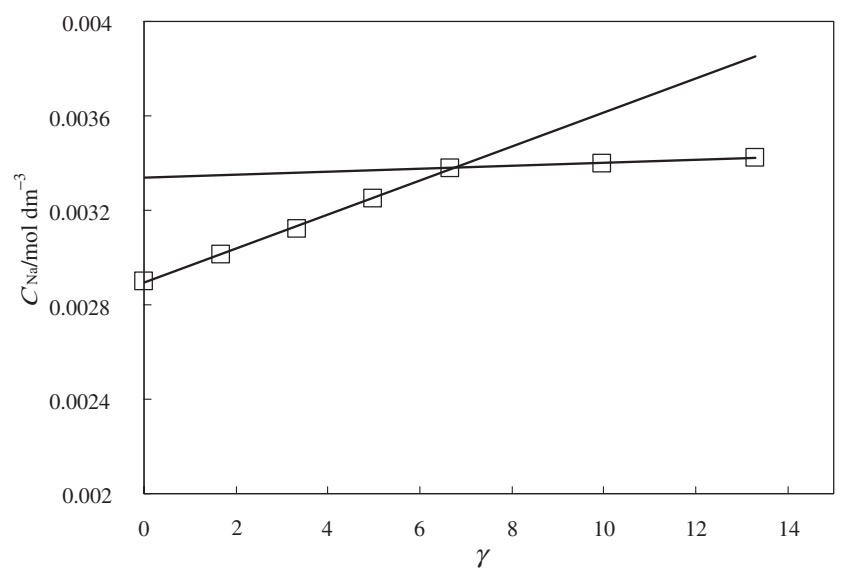

Figure 4. Concentration of $\mathrm{Na}^{+}$ions in $\mathrm{Na}_{2} \mathrm{ChS}-\mathrm{BSA}$ complex solution plotted against $\gamma$.

ed and became a constant value at about $\gamma=6.7$. That means in the region of $\gamma>6.7$, the binding of BSA to $\mathrm{Na}_{2} \mathrm{ChS}$ became saturated and no more $\mathrm{Na}^{+}$ion was released. That is, the number of BSA molecules binding to one $\mathrm{Na}_{2} \mathrm{ChS}$ molecule was about 6.7. The turn point in Figure 4 showed consistency with the results in measurement of mobility.

\section{Adsorption Amount $\Gamma$ of $\mathrm{Na}_{2} \mathrm{ChS}$ on BSA Monolayer}

To investigate the two dimensional interaction between $\mathrm{Na}_{2} \mathrm{ChS}$ and $\mathrm{BSA}$, the values of $\Gamma$ on BSA monolayer were measured at $25^{\circ} \mathrm{C}$ using a QCM method. A BSA monolayer was prepared by the method mentioned in a previous paper and used in this work as a BSA tip. ${ }^{16,17}$ The adsorption layer of $\mathrm{Na}_{2} \mathrm{ChS}$ was prepared by immersing the BSA tip into $\mathrm{Na}_{2} \mathrm{ChS}$ solution in various concentrations. The concentrations of $\mathrm{Na}_{2} \mathrm{ChS}$ solutions $C_{\mathrm{ChS}}$ were in the region of $2.2-22.0 \times 10^{-8} \mathrm{~mol} \mathrm{dm}^{-3}$. The values of $\Gamma$ of various $C_{\mathrm{ChS}}$ were obtained from the decrease of the frequencies of QCM when adsorption reached an equilibrium state. Figure 5 showed the adsorption behaviors of $\mathrm{Na}_{2} \mathrm{ChS}$ on BSA monolayer. As shown in Figure 5(a), the values of $\Gamma$ (shown by open squares) increased with increasing $C_{\mathrm{ChS}}$ and became an constant value of about $20 \mathrm{ng}$. The reciprocal plot of $\Gamma$ and $C_{\mathrm{ChS}}$ was linear as shown in Figure 5(b). The adsorption of $\mathrm{Na}_{2} \mathrm{ChS}$ on BSA monolayer was Langmuir type. The saturated adsorption amount $\Gamma^{\infty}$, which is about $21.6 \mathrm{ng} /$ per tip $\left(0.83 \times 10^{-6} \mathrm{~kg} \mathrm{~m}^{-2}\right)$, and the adsorption constant $K$ were calculated by using the Langmuir's adsorption isotherm equation. ${ }^{16}$ The results are shown in Table I with the results of BSA and NaHA serious, ${ }^{18}$ which were reported previously. The closed squares in Figure 5(a) show the calculated fitting values obtained from $K$ and $\Gamma^{\infty}$ using the Langmuir equation. They agreed well with the experimental results.

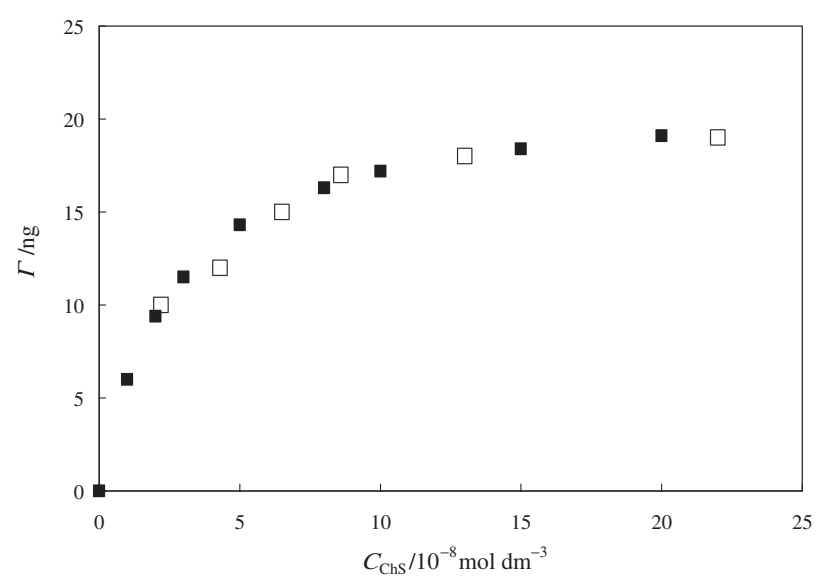

(a)

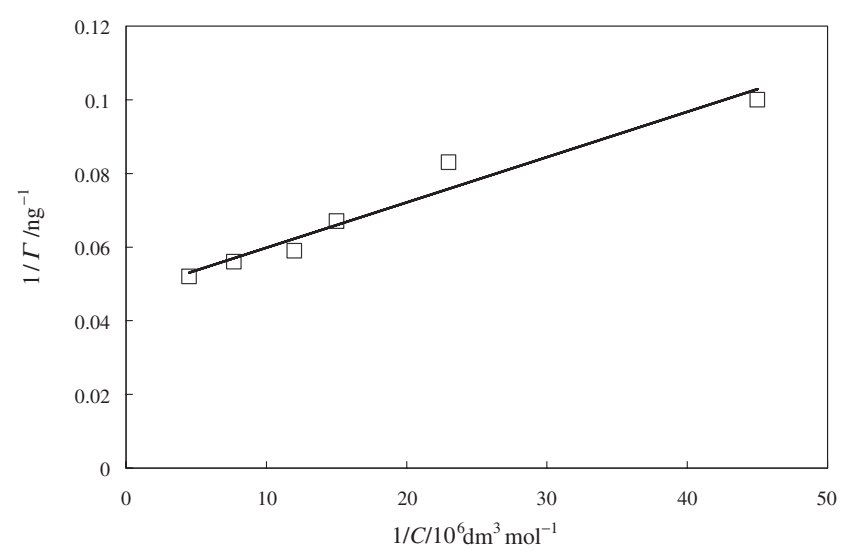

(b)

Figure 5. Adsorption behaviors of $\mathrm{Na}_{2} \mathrm{ChS}$ on BSA monolayer. (a) Values of $\Gamma$ of $\mathrm{Na}_{2} \mathrm{ChS}$ on BSA monolayer was shown by open squares. Closed squares show the calculated results obtained from $K$ and $\Gamma^{\infty}$ by Langmuir equation. (b) The reciprocal plots of $\Gamma$ and $C_{\mathrm{ChS}}$.

Table I. Adsorption characteristics of $\mathrm{Na}_{2} \mathrm{ChS}$, NaHA2.3 $\left(M_{\mathrm{w}}=23,000 \mathrm{~g} \mathrm{~mol}^{-1}\right)$ and NaHA85 $\left(M_{\mathrm{w}}=850,000 \mathrm{~g} \mathrm{~mol}^{-1}\right)$ on BSA monolayer

\begin{tabular}{lcccc}
\hline & BSA & NaHA2.3 & NaHA85 & $\mathrm{Na}_{2} \mathrm{ChS}$ \\
\hline$\left(K_{\mathrm{m}}\right) / 10^{7} \mathrm{dm}^{3} \mathrm{~mol}^{-1}$ & 9.45 & 38.0 & 1.22 & 3.86 \\
$\left(\Gamma^{\infty}\right) / 10^{-6} \mathrm{~kg} \mathrm{~m}^{-2}$ & 1.32 & 1.04 & 3.18 & 0.83 \\
$\left(\Gamma_{\mathrm{n}}^{\infty}\right) / 10^{-8} \mathrm{~mol} \mathrm{~m}^{-2}$ & 1.93 & 4.52 & 0.37 & 3.6 \\
$n_{\mathrm{BSA}} / n_{\text {gly }}$ & & 2.6 & 79 & 1.0 \\
\hline
\end{tabular}

$K_{\mathrm{m}}$ : adsorption constant. $\Gamma^{\infty}, \Gamma_{\mathrm{n}}^{\infty}$ : saturated adsorption amount. $n_{\mathrm{BSA}} / n_{g l y}$ : the molecular number of BSA on one glycosaminoglycan molecule.

\section{DISSCUSSION}

The Three-Diemensional Interaction between $\mathrm{Na}_{2} \mathrm{ChS}$ and $B S A$

Nakagaki and Sano reported that the $\mathrm{Na}_{2} \mathrm{ChS}$ molecules interacted electrostatically with the BSA molecules and formed a complex. ${ }^{21}$ In this work, the spec- 
tra of mobility shown in Figure 2 indicate that all BSA molecules bind to $\mathrm{Na}_{2} \mathrm{ChS}$ molecules and free BSA molecules are almost not exist in the region of $\gamma<6.7$. The saturated complex was formed in the solution of $\gamma=6.7$ and a free BSA peak appeared with increasing $\gamma$ further more.

In the low ionic strength $\left(J=0.001 \mathrm{~mol} / \mathrm{dm}^{-3}\right)$, $\mathrm{Na}_{2} \mathrm{ChS}$ molecules are unbranched linear anionic polyelectrolyte and stretch extensively due to the electrostatic repulsive force. They are a long rod-like shape of about $80 \mathrm{~nm}$ in long and $1 \mathrm{~nm}$ in diameter. The shape of the complex between $\mathrm{Na}_{2} \mathrm{ChS}$ and BSA was reported to be the same shape but their length was about $20 \mathrm{~nm}$ longer and the diameter was about $6 \mathrm{~nm}$ thicker. ${ }^{21}$ The values of $\mathrm{pH}$ of the complex solutions composed of $\mathrm{Na}_{2} \mathrm{ChS}$ and BSA used in this work was about 5.1 in our experimental conditions. At $\mathrm{pH}=5.1$, BSA molecules are charged a little positively as its isoelectric point of BSA was 5.2 and the $\mathrm{Na}_{2} \mathrm{ChS}$ molecules charged negatively. ${ }^{14}$ Then, the binding between them is considered to be contributed primarily by an electrostatic force. However hydrophobic force might somewhat exist.

As a result of the complex formation between BSA and $\mathrm{Na}_{2} \mathrm{ChS}$ molecules, $\mathrm{Na}^{+}$ions released from $\mathrm{Na}_{2} \mathrm{ChS}$ molecules. Since the $\mathrm{Na}_{2} \mathrm{ChS}$ molecule was charged by a carboxylic group and a sulfate group in every repeating unit, the reaction could be expressed by the following equation: ${ }^{21}$

$$
\begin{aligned}
& \left(\mathrm{NaSO}_{3} \mathrm{H}-\mathrm{Ch}-\mathrm{COONa}\right)_{n}+2 \mathrm{BSA} \\
& \quad \rightarrow \mathrm{BSA}\left(-\mathrm{SO}_{3} \mathrm{H}-\mathrm{Ch}-\mathrm{COO}-\right)_{n} \mathrm{BSA}+2 \mathrm{nNa}^{+}
\end{aligned}
$$

where $n$ is the number of repeating unit of $\mathrm{Na}_{2} \mathrm{ChS}$ binding to one BSA molecule. In the region of $\gamma<6.7$, assuming all BSA molecules added to $\mathrm{Na}_{2} \mathrm{ChS}$ solution bind to $\mathrm{Na}_{2} \mathrm{ChS}$ molecules, the value of $n$ could be calculated by eq 2 :

$$
n=\Delta C_{\mathrm{Na}+} / 2 C_{\mathrm{BSA}}
$$

where $C_{\mathrm{BSA}}$ is added BSA concentration and $\Delta C_{\mathrm{Na}+}$ is the concentration of released $\mathrm{Na}^{+}$ion.

Then, the values of $n$ can be obtained from the slope of $C_{\mathrm{Na}}$ shown in Figure 4. From the result of concentration of free $\mathrm{Na}^{+}$ion in the $\mathrm{Na}_{2} \mathrm{ChS}$ and BSA complex solution, the value of $n$ was obtained to be 7-8. That is, about seven or eight repeating units of $\mathrm{Na}_{2} \mathrm{ChS}$ molecule were binding to one BSA molecule. As reported before, ${ }^{15}$ the value of $n$ of NaHA was 15 . The repeating unit of NaHA has not sulfate group but only a carboxylic group, i.e., its charge density is a half of that of $\mathrm{Na}_{2} \mathrm{ChS}$. Then, the value of $n$ of $\mathrm{NaHA}$ is about two times of that of $\mathrm{Na}_{2} \mathrm{ChS}$. The result of $\mathrm{Na}_{2} \mathrm{ChS}$ was consistency well with those of NaHA. That is, their numbers of $\mathrm{Na}^{+}$ions replaced by one BSA molecule were both about 15 .
Since the molecular weight based on a repeating unit of $\mathrm{Na}_{2} \mathrm{ChS}$ is $489 \mathrm{~g} / \mathrm{mol}^{21}{ }^{21}$ one $\mathrm{Na}_{2} \mathrm{ChS}$ molecule is composed of 47 repeating units. Then, at the saturated binding, the number of BSA molecules on each $\mathrm{Na}_{2} \mathrm{ChS}$ molecule was obtained to be about $47 / 7 \approx$ 6.7. This calculated result was consistent with the value of $\gamma(=6.7)$ at the formation of the saturated complex obtained from the results of ELS and releases of $\mathrm{Na}^{+}$ion.

\section{Two-Dimensional Interaction between $\mathrm{Na}_{2} \mathrm{ChS}$ and $B S A$}

The results of QCM showed $\mathrm{Na}_{2} \mathrm{ChS}$ molecules adsorbed on BSA monolayer as the Langmuir adsorption type. $\mathrm{Na}_{2} \mathrm{ChS}$ solutions were about $\mathrm{pH} 5.8$ and the sulfate and carboxylic groups of $\mathrm{Na}_{2} \mathrm{ChS}$ molecules were almost in completely dissociated state. However, BSA molecules were nearly zero or negatively charged at this $\mathrm{pH}$. Then, the interaction between them was considered not an electrostatic one but almost a hydrophobic one, which was different from their interaction behaviors in solution.

The size of $\mathrm{Na}_{2} \mathrm{ChS}$ molecule is reported to be $80 \times 1 \mathrm{~nm}^{2}$ obtained by a light-scattering method. ${ }^{21}$ Assuming $\mathrm{Na}_{2} \mathrm{ChS}$ molecules adsorb onto BSA monolayer in a monolayer state, the saturated adsorption mass should be $12.4 \mathrm{ng} /$ per tip, which was calculated from the square of the QCM tip and the cross section of one $\mathrm{Na}_{2} \mathrm{ChS}$ molecule. Since the experimental value of $\Gamma^{\infty}$ was measured to be $21.6 \mathrm{ng}$ on one tip, the $\mathrm{Na}_{2} \mathrm{ChS}$ molecules might adsorbed in a double-layer state. However, NaHA was reported to adsorb onto BSA monolayer in 6-16 layers depending on its molecular weight. ${ }^{18}$ This may be resulted from the lower ability of self-assembly of $\mathrm{Na}_{2} \mathrm{ChS}$ molecule than that of NaHA. Furthermore, supposing only the lowest layer of $\mathrm{Na}_{2} \mathrm{ChS}$ participated in binding to BSA molecules, the value of $\gamma$ was estimated to be about 1 . It is much less than their combining ratio in the solution, which was calculated to be 7 BSA molecules on one $\mathrm{Na}_{2} \mathrm{ChS}$ molecule. It may be resulted from the stiffness and the shape of $\mathrm{Na}_{2} \mathrm{ChS}$ or the limited space at interface. And if comparing with NaHA2.3, which has the same molar weight as $\mathrm{Na}_{2} \mathrm{ChS}$, the value of $\gamma$ was also much smaller than that of $\mathrm{Na}_{2} \mathrm{ChS}$ as shown in Table I. This is considered to relative to the net work structure of NaHA2.3 on BSA monolayer. ${ }^{18}$ The nano structure and nano properties of $\mathrm{Na}_{2} \mathrm{ChS}$ at interface should be investigated further.

\section{CONCLUSIONS}

In solution, $\mathrm{Na}_{2} \mathrm{ChS}$ could binds to BSA by an electrostatic force primarily and forms soluble complexes. However, a hydrophobic force was found to partici- 
pate in the interaction between them at interface. The values of $\gamma$ at the saturated state were much bigger in solution than that at interface. From discussing the charge densities of $\mathrm{Na}_{2} \mathrm{ChS}$ and NaHA in solution, their difference in the number of repeating units binding to one BSA at a saturated state is consistent with their difference in charge density. At interface, their values of $\gamma$ are also different because of the difference in self-assembled nano structure.

\section{REFERENCES}

1. E. Ruoslahti, Annu. Rev. Cell Dev. Biol., 4, 229 (1988).

2. F. B. Anne, S. Evan, and D. W. Richard, Am. Fam. Physician, 73, 1245 (2006).

3. Anon, Health News, 12, 5 (2006).

4. J. G. Barnhill, C. L. Fye, D. W. Williams, D. J. Reda, C. L. Harris, and D. O. Clegg, J. Am. Pharm. Assoc., 46, 14 (2006).

5. C. H. Chang, T. F. Kuo, C. C. Lin, C. H. Chou, K. H. Chen, F. H. Lin, and H. C. Liu, Biomaterials, 27, 1876 (2006).

6. G. Rainer, R. Menapace, K. Schmid, S. Sacu, B. Kiss, G. Heinze, and O. Findl, Ophthalmology, 112, 1714 (2005).

7. I. Yamaguchi, S. Iizuka, A. Osaka, H. Monma, and J. Tanaka, Colloids Surf., A, 214, 111 (2003).

8. M. Rehakova, D. Bakos, K. Vizarova, M. Soldan, and M. Jurickova, J. Biomed. Mater. Res., 30, 369 (1996).

9. R. N. Chen, G. M. Wang, C. H. Chen, H. O. Ho, and M. T. Sheu, Biomacromolecules, 7, 1058 (2006).

10. V. Nicola and M. Francesca, J. Chromatogr., B: Anal.
Technol. Biomed. Life Sci., 834, 1 (2006).

11. D. H. Vynios, N. K. Karamanos, and C. P. Tsiganos, J. Chromatogr., B: Anal. Technol. Biomed. Life Sci., 781, 21 (2002).

12. R. L. Jackson, S. J. Busch, and A. D. Cardin, Physiol. Rev., 71, 481 (1991).

13. M. M. Maimone and D. M. Tollefse, J. Biol. Chem., 265, 18263 (1990).

14. M. Yonese, S. Xu, S. Kugimiya, S. Sato, and I. Miyata, Prog. Colloid Polym. Sci., 106, 252 (1997).

15. S. Xu, J. Yamanaka, S. Sato, I. Miyata, and M. Yonese, Chem. Pharm. Bull., 48, 779 (2000).

16. T. Nonogaki, S. Xu, S. Kugimiya, S. Sato, I. Miyata, and M. Yonese, Langmuir, 16, 4272 (2000).

17. S. Xu, T. Nonogaki, K. Tachi, S. Sato, I. Miyata, J. Yamanaka, and M. Yonese, Stud. Surf. Sci. Catal., 132, 889 (2001).

18. S. Xu, S. Sato, I. Miyata, J. Yamanaka, and M. Yonese, Mol. Simul., 29, 711 (2003).

19. S. Xu, J. Yamanaka, S. Sato, I. Miyata, and M. Yonese, Colloid Polym. Sci., 282, 440 (2004).

20. S. Xu, Y. Song, S. Sato, I. Miyata, J. Yamanaka, and M. Yonese, Colloid Polym. Sci., 283, 383 (2005).

21. M. Nakagaki and Y. Sano, Bull. Chem. Soc. Jpn., 45, 1011 (1972).

22. M. Hara, M. Higuchi, N. Minour, S. Ohuchi, C. S. Cho, T. Akaike, and A. Higuchi, Nippon Kagaku Kaishi, 5, 483 (1996).

23. Y. Okahata, K. Kimura, and K. Ariga, J. Am. Chem. Soc., 111, 9190 (1989). 